\title{
Extended Battery to Cope with ELAP for APR1400
}

\author{
Hamdy Samier Hamdy Abdelbadea and Chang Choong-Koo \\ KEPCO International Nuclear Graduate School-KINGS, 658-91 Haemaji-ro, Seosaeing-myeon,, Ulju-gun, Ulsan 689-882, Koera
}

Received: October 17, 2016 / Accepted: October 31, 2016 / Published: January 31, 2017.

\begin{abstract}
Since the Fukushima nuclear accident, the interest in securing a reliable emergency power has increased, and as follow-up measures, each country is conducting various studies for enhancement of safety such as re-examination of EDG (emergency diesel generator) capacity, securement of additional emergency power, etc. This study was performed to find the way to implement a reliable DC system in coping with 72 hours extended station blackout for APR1400 within the battery room size. By using the largest capacity battery in the market which satisfies the requirements for Class $1 \mathrm{E}$ to perform a duty cycle for 24 hours, after the decay of the qualified class-1E lead acid battery a Non-Class $1 \mathrm{E}$ Lithium ion based battery system can be used as a backup system for 48 hours.
\end{abstract}

Key words: Station blackout, ELAP (extended loss of AC power), FLEXES equipment, Non-Class-1E Lithium ion based system.

\section{Acronyms}

$\begin{array}{ll}\text { AAC } & \text { Alternating AC source } \\ \text { AFW-ISO valve } & \text { Auxiliary feed water isolation valve } \\ \text { BOP } & \text { Balance of plant } \\ \text { DC } & \text { Direct current } \\ \text { EDG } & \text { Emergency diesel generator } \\ \text { ELAP } & \text { Extended loss of alternating power source } \\ \text { IP } & \text { Instrumentation power } \\ \text { IWS } & \text { In-containment water storage } \\ \text { LCP } & \text { Local control panel } \\ \text { LRC } & \text { Locked rotor current } \\ \text { MDG } & \text { Mobile diesel generator } \\ \text { MOV } & \text { Motor operated valve } \\ \text { NSSS } & \text { Nuclear steam supply system } \\ \text { POSRV } & \text { Pilot operated safety relief valve } \\ \text { RCS Valve 2 } & \text { Reactor coolant system valve 2 } \\ \text { SWGR\& LC } & \text { Switchgear and load centers } \\ \text { SIS } & \text { Safety injection system } \\ \text { TD-AFW } & \text { Turbine driven auxiliary feed water }\end{array}$

\section{Introduction}

\subsection{Background}

A SBO (station blackout) is defined as the loss of all AC power at an NPP (nuclear power plant). This is a loss of off-site power together with a failure of the

Corresponding author: Chang Choong-Koo, Ph.D., professor, research field: nuclear power plant engineering. on-site emergency backup generators to operate. Per NRC Regulations Title 10, CFR (code of federal regulations) 50.63 "Loss of all alternating current power", all nuclear power plants have a coping capability for SBO conditions for a limited time period ranging from approximately two to sixteen hours. An ELAP (extended loss of AC power) event is defined as a loss of all off-site and on-site AC power sources for an indeterminate period of time, which will challenge the long-term cooling of the reactor core and the SFP (spent fuel pool) unless mitigating actions are taken. This extended requirement is the result of the events at Fukushima.

Fukushima accident is the event which shows how the natural accident can lead the plant to a complete loss all of alternating current (LOOP (loss of offsite power)) which initiates a complete and extended SBO. The operators lost the ability to cool the fuel in the Unit 1 reactor after several hours. As Unit 2 \& 3 DC battery system was still supplying power to Controlled Steam-Driven RCIC (reactor core isolation cooling), the RCIC was operated and got the ability to cool the reactor for more time in both units. The operator lost the ability to cool the fuel in Unit 3 reactor after about 30 hours, and in the Unit 2 reactor after about 70 
hours, resulting in damage to the nuclear fuel shortly after the loss of cooling capabilities [1].

APR1400 is equipped with AFWS (auxiliary feed-water system) in order to provide an independent safety-related means of supplying secondary-side with quality feed-water to the steam generator(s) for removal of heat and prevention of reactor core uncovery during emergency phases of plant operation. This system is designed to be automatically or manually initiated, supplying feed-water to the steam generators for any event that results in the loss of normal feed-water and requires heat removal through the steam generators, including the loss of normal onsite and normal offsite AC power. Following the event, the AFWS is the only way to maintain adequate feed-water inventory in the steam generator(s) for residual heat removal and it is capable of maintaining hot standby and bringing the plant to cool shutdown condition. All controls, instrumentation, and valves, which are essential to the emergency operation of the turbine-driven pumps subdivisions, are powered by battery-backed Class $1 \mathrm{E}$ power. The batteries are capable of powering the auxiliary feed-water turbine-driven pump and subdivisions for a station blackout (station loss of all AC power) up to eight hours with appropriate load shedding and the cooling capability will remain up to the depletion of the Class 1 E battery system [2].

Extended station blackout coping capabilities of APR1400 which is a research done on the APR1400 by other researchers by applying an ELAP analyses using the MAAP severe accident computer code concludes that in case of failure of both EDG and AAC-DG, the extension of I\&C loads associated with the TD-AFW may be necessary to assure the coping integrity for safe shutdown and more efficient core cooling capability [3].

The main goal of this study is to survey current practices and problems in NPP battery-based back-up power, and to find the way to improve the current DC system based on new technologies in accordance with the new requirements raised by nuclear regulatory authority after Fukushima Daiichi accident. These provided information of current practices and potential interest in applying new energy storage technology solutions. Subsequently, calculated required battery capacity to cope with ELAP in APR1400 nuclear power plants to propose solutions for the safety related DC system in future power plant designs.

\subsection{The DC Power System in APR1400}

The APR1400 nuclear power plant is provided with DC (direct current) systems, which are classified into Class-1E system and Non-Class $1 \mathrm{E}$ system and designed to provide DC power for DC motor operated valves and for various NSSS and BOP control and instrumentation systems, as well as providing DC power for the turbine/generator emergency loads during normal and abnormal operating conditions [2]. The Class 1E DC system consists of four $125 \mathrm{~V} \mathrm{DC}$ power systems per unit. The batteries are sized in accordance with the recommendations in KEPIC EEG 1,100 (IEEE 485). Each Class-1E battery rating is as follows:

\begin{tabular}{ll}
\hline Battery type & Lead acid \\
Number of cells (channel A \& B) & 58 Cell $\times 2$ (parallel) \\
Number of cells (channel C \& D) & 58 Cell $\times 3$ (parallel) \\
Total nominal voltage & $125 \mathrm{~V} \mathrm{DC}$ \\
Battery capacity (channel A \& B) & $(2,800 \mathrm{AH})$ \\
Battery capacity (channel C \& D) & $(4,200 \mathrm{AH})$ \\
Minimum operating voltage & $1.81 \mathrm{~V} / \mathrm{cell}$ \\
Voltage range & $105-140 \mathrm{~V} \mathrm{DC}$ \\
\hline
\end{tabular}

\section{New Regulatory Guide Recommendations}

\subsection{US-NRC Recommendations}

After Fukushima accident, the NTTF (near-term task force)-which consisted of a group of senior NRC staff-NTTF suggested enhanced station blackout mitigation strategies, within NTTF Recommendation 4.1, as follows: Initiate rulemaking to revise $10 \mathrm{CFR}$ 50.63 to require each operating and new reactor licensee to [4-7]: 
- Establish a minimum coping time of 8 hours for a loss of all ac power;

- Establish the equipment, procedures, and training necessary to implement an "extended loss of all ac" coping time of 72 hours for core and spent fuel pool cooling and for reactor coolant system and primary containment integrity as needed;

- Preplan and pre-stage offsite resources to support uninterrupted core and spent fuel pool cooling, and reactor coolant system and containment integrity as needed, including the ability to deliver the equipment to the site in the time period allowed for extended coping, under conditions involving significant degradation of offsite transportation infrastructure associated with significant natural disasters.

\subsection{Nuclear Energy Institute Recommendations}

The underlying strategies for NEI (Nuclear Energy Institute) Diverse and Flexible Coping Strategies (FLEX) Implementation Guide (NEI 12-06, Aug. 2012) recommended a three-phase approach:

(1) Initially cope by relying on plant equipment.

(2) Augment plant equipment with sufficient on-site FLEX equipment and consumables should be provided for $24 \mathrm{~h}$ from the event initiation to maintain or restore key functions.

(3) Obtain additional capability and redundancy from off-site equipment until power, water, and coolant injection systems are restored or commissioned.

On-site resources will be used to cope with the first two phases of the casualty for a minimum of the first 24 hours of the event. The site-specific ELAP analysis will dictate the deployment schedule for off-site equipment. The delivery schedule for the off-site equipment must allow for sufficient margin to meet the deployment times of the off-site equipment. The schedule for initial delivery of off-site equipment (equipment needed to back up on-site equipment and extend the coping duration) needs to be contractually arranged with the off-site facility. This strategy means with the failure of EDG and AAC-DG, the $125 \mathrm{~V}$ DC Class $1 \mathrm{E}$ batteries to last for 24 hours [8].

These requirements can be achieved by the following:

- Load-shedding scheme;

- Sizing channel C \& D with large capacity battery;

- Cross-tying batteries between divisions;

- Delayed battery operation.

\section{Current APR1400 Coping Capabilities}

\subsection{Coping with $S B O$}

As shown in Fig. 1 each division of the $4.16 \mathrm{kV}$ AC Class 1E auxiliary power system is supplied with emergency standby power from an independent EDG. The EDG is designed in accordance with the USNRC regulatory guide RG1.32 and international Standard IEEE 308 and sized with sufficient capacity to enable all the needed ESF and emergency shutdown loads powered from its respective Class $1 \mathrm{E}$ buses. Each EDG is designed to attain rated voltage and frequency within $17 \mathrm{~s}$ after receipt of start signal, supply power to $4.16 \mathrm{kV} \mathrm{AC}$ Class $1 \mathrm{E}$ bus within $19 \mathrm{~s}$, and begin to accept sequenced loads to meet the response times. After LOOP, operation and loads sequencing of EDG is operated automatically [9].

In case that EDG fails to start, each two NPP units in the plant were equipped with AAC Diesel Generator designed in accordance with the regulatory guide RG 1.155 in early preparation for the case of simultaneously unserviceable off-site power and on-site power (main generator, emergency generator) [3].

AAC D/G has a sufficient amount of capacity to supply power to the auxiliaries of safety shutdown load and alternating current power will be connected to the $4.16 \mathrm{KV}$ Class-1E bus during the SBO event. It should be designed in the way that it can supply power again within $10 \mathrm{~min}$ after on-site power outage. Every operation related to alternating current power is 


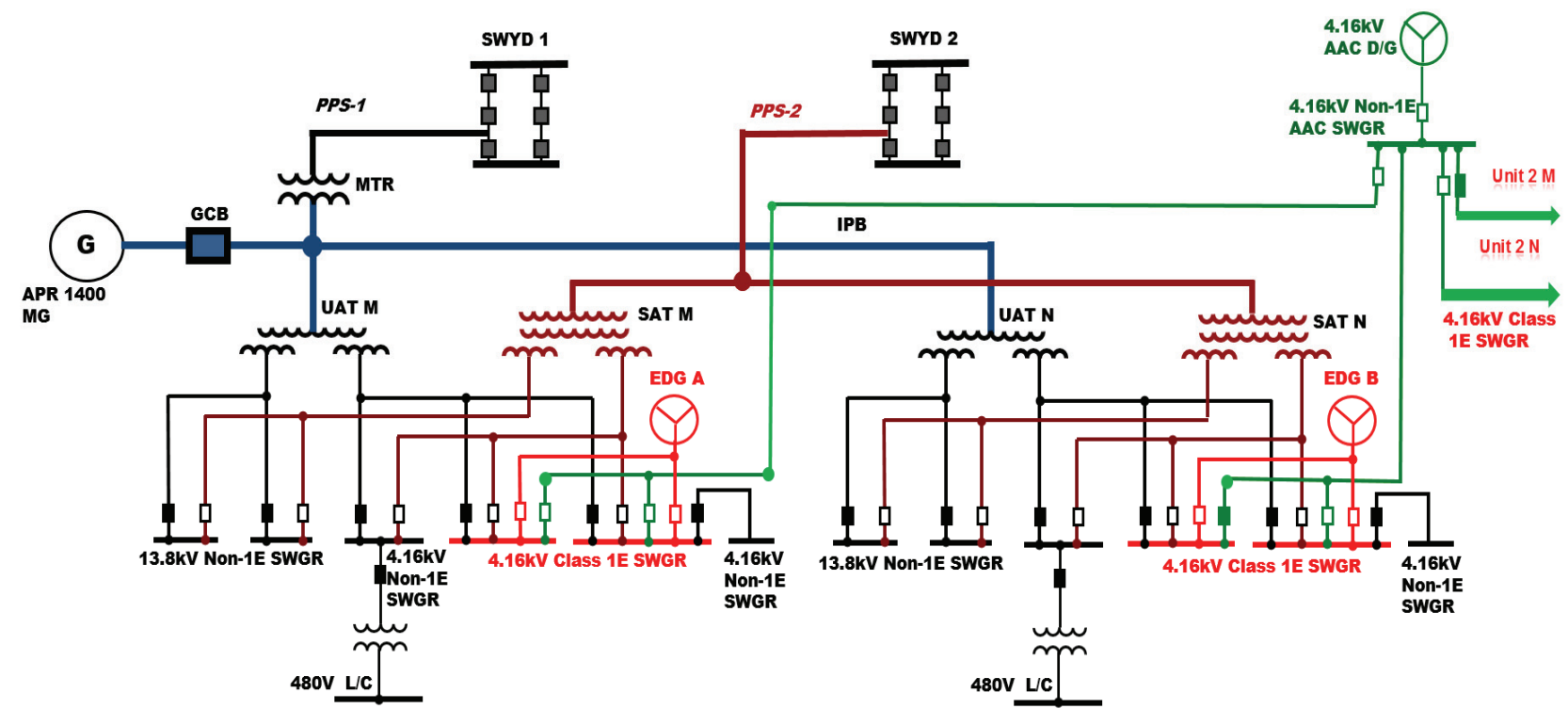

Fig. 1 APR1400 auxilary power system configuration.

performed manually. AAC D/G supplied with sufficient fuel enough to maintain continuous operation for $24 \mathrm{~h}$, $8,700 \mathrm{~kW}$ is rated power on continuous operation (22 h) and 9,750 kW on short-time operation (2 h) [9].

\subsection{Coping with ELAP}

In Korea, in response to the severe accident and long-term station blackout, each plant site is equipped with a mobile generator and a storage battery (including charger and cable), to supply power to the safety related loads within $2 \mathrm{~h}$ after any accidents by securing temporary power connection points. The mobile DG is rated at $1,500 \mathrm{~kW}$ and connected to the $4.16 \mathrm{kV}$ Class-1E buses to cope with a complete station blackout SBO scenario [9].

\section{The Proposed Strategy for Coping 72 h SBO}

According to NEI recommendation, the plant shall rely on the onsite equipment to cope with ELAP situation for $24 \mathrm{~h}$ until the access route is recovered, but with the concurrent failure of EDG and AAC supply, $125 \mathrm{~V}$ DC Class 1E systems should remain able to supply the safety related loads for $24 \mathrm{~h}$. As EnerSys Gn-45 with nominal capacity 3,600 Ah is the
Table 1 WB-LYP10000AH general specifications.

\begin{tabular}{|c|c|}
\hline Nominal voltage & $2.8 \mathrm{~V}$ \\
\hline Operating temperature & $-45 \sim 85^{\circ} \mathrm{C}$ \\
\hline Maximum continuous discharge current & $\leq 1 \mathrm{CA}$ \\
\hline Maximum impulse discharge current & $\begin{array}{l}\leq 20 \mathrm{CA} \\
\text { (impulse current) }\end{array}$ \\
\hline Standard charge/discharge current & $0.5 \mathrm{CA}$ \\
\hline Battery dimensions & $\begin{array}{l}(\mathrm{L}(687), \mathrm{W}(367) \text {, } \\
\text { and } \mathrm{H}(756) \mathrm{mm})\end{array}$ \\
\hline Weight & $335 \mathrm{~kg}$ \\
\hline
\end{tabular}

largest qualified Class 1E battery in the market, it recommended to be used as a stationary class $1 \mathrm{E}$ DC source to supply the critical loads for channel C \& D up to $24 \mathrm{~h}$, after the decay of the battery the WB-LYP lithium ion battery will be used as a Non-Class $1 \mathrm{E}$ backup source for the class $1 \mathrm{E} 125 \mathrm{~V}$ DC source for $48 \mathrm{~h}$. WB-LYP10000AH general specifications will be as Table 1 [12].

Energy's Power safe GN-45 general specifications are listed in Table 2 [10].

\section{The Loads Considered to Cope with ELAP}

A typical nuclear power plant will include both $\mathrm{AC}$ and DC loads. The DC loads, with battery backup, are designed to carry out all critical plant operations even 
Table 2 Enersys Gn-45 general spesification.

\begin{tabular}{|c|c|c|c|c|c|c|c|c|c|c|c|c|c|c|c|}
\hline \multirow{3}{*}{$\begin{array}{l}\text { Battery } \\
\text { type }\end{array}$} & \multirow{3}{*}{$\begin{array}{l}\text { NOM } \\
\text { Ah Cap }\end{array}$} & \multicolumn{6}{|c|}{ Nominal dimensions } & & & & & & & & \\
\hline & & \multicolumn{2}{|c|}{ Length } & \multicolumn{2}{|c|}{ Width } & \multicolumn{2}{|c|}{ Height } & \multicolumn{2}{|c|}{ Unpacked } & \multicolumn{4}{|c|}{ Domestic packed } & \multicolumn{2}{|c|}{$\begin{array}{l}\text { Electrolyte } \\
\text { only/1215SG }\end{array}$} \\
\hline & & In & $\mathrm{mm}$ & In & $\mathrm{mm}$ & In & $\mathrm{mm}$ & Ibs & $\mathrm{Kg}$ & Ibs & $\mathrm{kg}$ & Ibs & $\mathrm{kg}$ & gal & ltr \\
\hline GN-45 & 3,600 & 16.6 & 422 & 15.1 & 384 & 27.2 & 691 & 705 & 320 & 727 & 330 & 140 & 63 & 14 & 53 \\
\hline
\end{tabular}

Table 3 Channel C load profile for $24 \mathrm{~h}$.

\begin{tabular}{|c|c|c|c|c|c|}
\hline \multirow{2}{*}{$125 \mathrm{~V} \mathrm{DC}$ load name } & \multicolumn{2}{|c|}{$\begin{array}{c}\text { Continuous } \\
24 \mathrm{~h}\end{array}$} & \multirow{2}{*}{$\begin{array}{l}\text { Non-continuous } \\
24 \mathrm{~h} \\
\end{array}$} & \multirow[t]{2}{*}{ Momentary } & \multirow[t]{2}{*}{ Random } \\
\hline & $2 \mathrm{~h}$ & $22 \mathrm{~h}$ & & & \\
\hline MOV Inverter SI no-load current & 40 & 40 & & & \\
\hline IWS valve 1 & & & & & 229.6 \\
\hline IWS valve 2 & & & & & 229.6 \\
\hline RCS valve & & & & & 58.8 \\
\hline RCS valve 2_LRC & & & & & 581.2 \\
\hline AFP turbine LCP & 8.8 & 8.8 & & $68.8($ note 1$)$ & \\
\hline AFW ISO-valves & & & 180 (note 2 ) & & \\
\hline Reactor trip switchgear system & & & & $3($ note 1$)$ & \\
\hline EDG A-control panel & 7.3 & 7.3 & & & \\
\hline $\begin{array}{l}\text { Lamp and relay, trip of medium \& low } \\
\text { voltage SWGR \& LC }\end{array}$ & 4.3 & 4.3 & & $34.3($ note 1$)$ & \\
\hline IP inverter & 247.4 & 73.8 & & & \\
\hline
\end{tabular}

Note (1): A momentary load which occurs at the 1 st minute of the battery duty cycle $(0 \sim 1 \mathrm{~min})$.

Note (2): A random load of (180 A) is loaded 5 min every hour.

if the normal AC power is lost. Loads that are not likely to be on the DC system are space conditioning, non-critical lighting, and convenience receptacles. Otherwise all equipment necessary for the plant to function and provide required circuit control and protection would operate from the DC bus or via IP system providing AC power with DC battery backup.

The loads are classified into continuous, non-continuous, momentary and random loads in accordance with IEEE 485 and based on the battery duty cycle as listed in Table 3 [11].

\section{Battery Sizing Calculation Procedures and Results}

\subsection{Sizing Criteria}

The DC battery sizing calculation will follow the following criteria:

- The battery sized to supply the loads for $2 \mathrm{~h}$ without load shedding, and $22 \mathrm{~h}$ with applying load shedding;
- The minimum allowable cell voltage at any time in the duty cycle is considered to be $1.81 \mathrm{~V} \mathrm{PC}$;

- A minimum electrolyte temperature of $65{ }^{\circ} \mathrm{F}$ $\left(18.3{ }^{\circ} \mathrm{C}\right)$ shall be used in derating battery capacities;

- To account for future DC loads, a design margin of $15 \%$ shall be added, it can be reduced to $10 \%$ in order to avoid excessive margin;

- An aging factor of $25 \%$ will be considered for Lead acid battery;

- A temperature correction factor will be considered for Lead Acid batteries as $8 \%$;

- An aging factor of $15 \%$ will be considered for L-Ion batteries;

- $20 \%$ will be considered for temperature correction.

\subsection{Calculation Procedure}

The Battery sizing calculations were calculated in accordance with IEEE 485 and IEEE 946 using the following procedure.

- Constant-power-load currents had been 
calculated based on minimum allowable battery voltage of $105 \mathrm{~V}$ DC. For conservatism, $100 \mathrm{~V}$ DC at load terminal was used in the calculation to account for voltage drop;

- Random load assignment is accomplished by first sizing the battery without the random load to determine the most limiting period of the duty cycle. The random load is then assigned to the end of the most limiting period and the battery size recalculated;

- Calculated battery size is corrected for a minimum temperature of $65^{\circ} \mathrm{F}\left(18.3^{\circ} \mathrm{C}\right)$ with $15 \%$ margin and $25 \%$ added for aging;

- The K-factor curve of vented lead acid GN-45 was used for battery sizing calculation.

\subsection{Results and Discussion}

By applying EnerSys Gn-45 battery, channel C \& D battery shall be sized to 7,200 Ah to cope with $24 \mathrm{~h}$ SBO. As the current dimension of the battery room for
Shin Kori 5, $6 \mathrm{~L}(11.76 \mathrm{~m}) \times \mathrm{D}(8.534 \mathrm{~m})$ is one of the factors that should be considered, the room can allow to implement the proposed strategy by limiting the installation and the spacing between each two tires to $600 \mathrm{~mm}$ as shown in Fig. 2, enough space will be saved to implement a supplementary backup source to cope with the last $48 \mathrm{~h}$.

Table 4 Load profile for DC backup system.

\begin{tabular}{lll}
\hline & \multicolumn{2}{l}{ Estimated load (A) } \\
\cline { 2 - 3 } Load name & $\begin{array}{l}55 \mathrm{~min} \times \\
48 \text { cycles }\end{array}$ & $\begin{array}{l}5 \mathrm{~min} \times \\
4 \mathrm{cycles}\end{array}$ \\
\hline $\begin{array}{l}\text { MV \& LV switchgear control } \\
\text { Safety depressurization valve }\end{array}$ & 4.3 & 4.3 \\
$\begin{array}{l}\text { Inverter no-load current } \\
\text { Aux. feed-water isolation valve }\end{array}$ & 40 & 40 \\
$\begin{array}{l}\text { Instrument power inverter } \\
\text { channel C }\end{array}$ & 73.8 & 780 \\
$\begin{array}{l}\text { Miscellaneous valves } \\
\text { Reactor trip SWGR }\end{array}$ & 7.2 & 7.2 \\
AFW turbine local control panel & 8.8 & 8.8 \\
Total & 134.1 & 314.1 \\
\hline
\end{tabular}

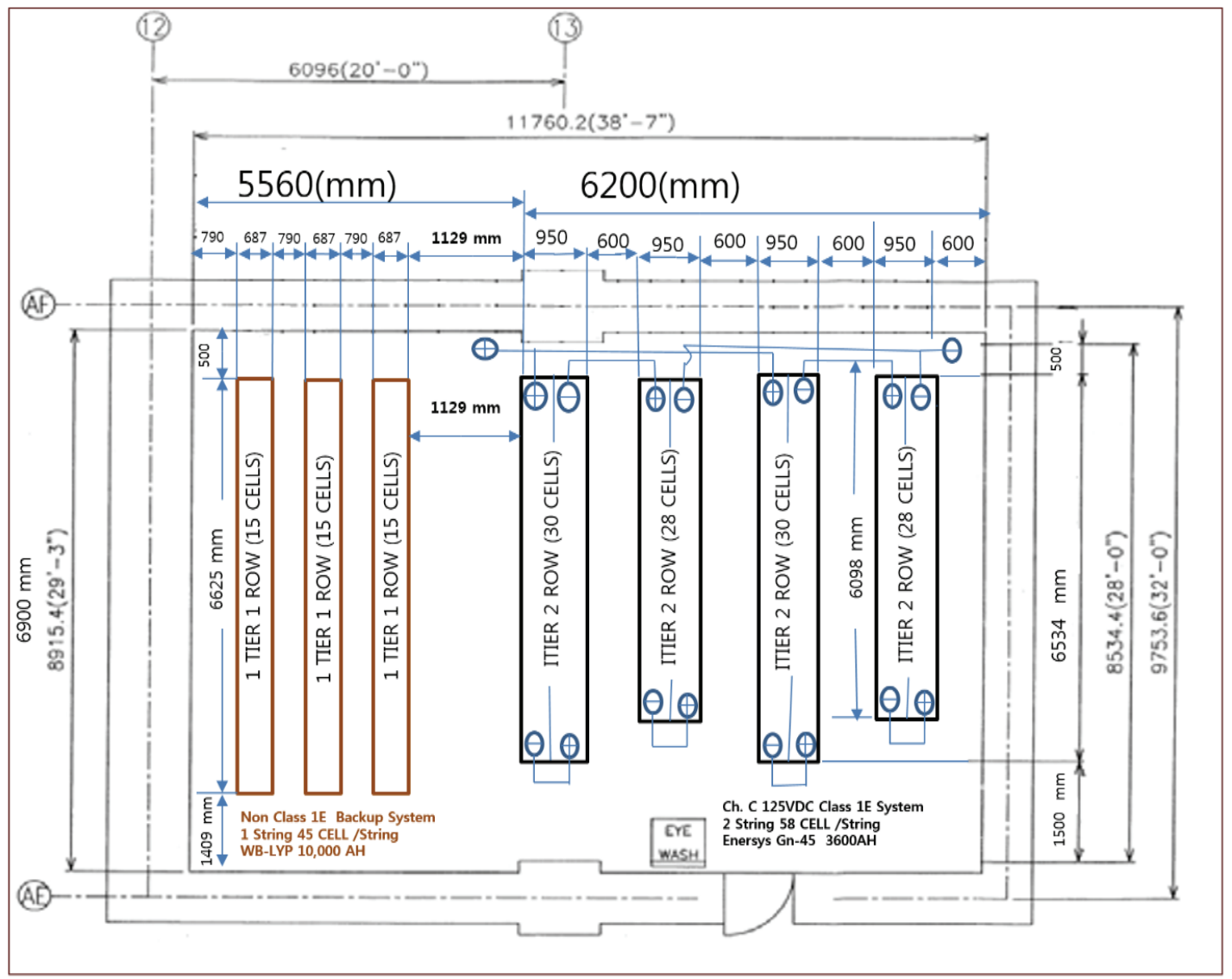

Fig. 2 Battery room proposed configuration. 
Table 5 Class $1 \mathrm{E}$ and Non Class $1 \mathrm{E}$ combined battery system.

\begin{tabular}{ll}
\hline Type & Vented lead acid \\
Battery model & EnerSys GN-45, 3,600Ah \\
$\begin{array}{l}\text { Number of cells } \\
\text { (channel C \& D) }\end{array}$ & 58 Cell $\times 2$ (parallel) \\
Qualification & 10CFR50 Appendix B, and \\
& ASME NQA-11994 \\
& IEEE-323-1974, \\
Industrial standard & IEEE-344-1987, \\
& IEEE-450-2002, \\
Total nominal voltage & IEEE-535-2006 \\
Battery capacity & 125 V DC \\
(channel C \& D) & 7,200 Ah \\
Minimum operating voltage & 1.81 V/cell \\
Voltage range & $105-140$ V DC \\
Non-class 1E & 125 V DC source \\
Battery type & lithium-ion \\
Number of cell per string & 45 cell/string \\
Number of string & 1 string \\
Voltage range & $105-140$ V DC \\
Total battery model \& capacity & WB-LYP 10,000AH \\
\hline
\end{tabular}

Required capacity for backup system using lithium ion battery (WB-LYP type) was calculated based on the load profile shown in Table 4.

The capacity required for DC-backup source $=$

$$
\begin{gathered}
134.1 \mathrm{~A} \times 55 / 60 \mathrm{H} \times 48 \text { Cycles }+ \\
314.1 \mathrm{~A} \times 5 / 60 \mathrm{H} \times 48 \mathrm{Cycles}=7,156.8 \mathrm{Ah} \\
7,156.8 \mathrm{Ah} \times 1.35=9661.68 \mathrm{Ah}
\end{gathered}
$$

where 1.35 is safety margin and consists of the following factors;

Design margin: $10 \%$;

Aging margin: $25 \%$;

$\mathrm{K}$ factor (assumed): 1.

The calculation results for the lithium ion battery show that a 9,661 Ah is required to be a backup source after the depletion of the lead acid battery. This amount of capacity can be achieved by using WB-LYP 10,000 AH. The system's proposed specifications and ratings will be as in Table 5 .

\section{Conclusions}

Throughout this work, Class 1E 125 V DC system for both channels C \& D can be sized to cope with 72 $\mathrm{h}$ Extended station blackout by utilizing the largest qualified vented lead acid battery (EnerSys Gn-45) type for $24 \mathrm{~h}$ and applying lithium ion (WB-LYP $10000 \mathrm{Ah}$ ) battery for both channels as supplementary source for 48 hours. As the proposed system will exist at the class $1 \mathrm{E}$ battery room, so the system shall pass the seismic qualification test to be applied for APR1400 NPP.

\section{Acknowledgement}

This research was supported by the 2016 Research Fund of the KEPCO International Nuclear Graduate School (KINGS), Republic of Korea.

\section{References}

[1] http://www.world-nuclear.org/information-library/safetyand-security/safety-of-plants/fukushima-accident.aspx.

[2] APR1400 Design Control Document.

[3] Lee, S. W., Hong, T. H., Seo, M. R., Lee, Y. S., and Kim, H. T. Extended Station Blackout Coping Capabilities of APR1400.

[4] NRC Guidance for Implementing the SBO Rule, In Regulatory Guide (RG) 1.155.

[5] Robustness of Electrical Systems of Nuclear Power Plants in Light of the Fukushima Daiichi Accident (ROBELSYS) Workshop Proceedings, Paris, France April $1-4,2014$.

[6] NRDC's Petition for Rulemaking to Revise 10 C.F.R.350.63.

[7] Rulemaking for Station Blackout Mitigation Strategies RIN number: 3150-AJ08 NRC Docket ID: NRC-2011-0299 Regulatory Basis Document.

[8] NEI. Diverse and Flexible Coping Strategies (FLEX) Implementation Guide. Nuclear Energy Institute.

[9] Emirates Nuclear Energy Corporation, Barakah NPP Unit 3\&4, Preliminary Safety Analysis Report.

[10] EnerSys Brochure (Power Safe) Publication No: US-GN-RS-002. 2012.

[11] Final safety analysis report (FSAR: Shin Kori Unit 3, 4).

[12] Thunder Sky Winston Rare Earth Lithium Ion Battery Specification. 